\title{
Forecasting world transport in the year 2050
}

\author{
Patrick Moriarty \\ Department of Mechanical Engineering, Monash University, \\ Caulfield Campus PO Box 197, Caulfield East, Victoria 3145 \\ Australia \\ E-mail: patrick.moriarty@eng.monash.edu.au
}

\section{Damon Honnery}

Department of Mechanical Engineering, PO Box 31, Monash University, Victoria 3800 Australia

E-mail: damon.honnery@eng.monash.edu.au

\begin{abstract}
This paper examines what can be known about transport technology and travel volumes out to the year 2050, mainly in the industrialised countries. Analysis of the past 50 years in transport shows that adoption of radically new technology has been comparatively slow. Travel volumes and vehicle fleets have risen roughly in step with national income. The next half-century, however, will likely see major changes in transport technology and fuels, in response to perceived constraints like oil depletion and global warming. The inevitable uncertainty in long-term forecasting will be exacerbated by these constraints. A break in the travel/ income relationship, as has already happened with the energy/income relationship, is also probable. Responding to an uncertain future will prove difficult if change is left largely to market forces. Instead, a larger role for government can both reduce uncertainty and provide us with a more sustainable transport system.
\end{abstract}

Keywords: Air transport, future prediction, global travel, historical travel data, possible futures, preferred futures, probable futures, surface transport, technology forecasting, transport technology.

Reference to this paper should be made as follows: Moriarty, P. and Honnery, D. (2004) 'Forecasting world transport in the year 2050', Int. J. Vehicle Design, Vol. 35, Nos. 1/2, pp. 151-165.

\section{Introduction}

Predicting long-term future transport technology and travel is important for several reasons. Firstly, the infrastructure is expensive and long-lived. The new City Link tollway in Melbourne, Australia, for example illustrates this point. The $21 \mathrm{~km}$ tollway took about five years to plan and build. It will operate privately for 35 years, and then be handed over to the state government [1]. Calculating investor returns at the project planning stage involved estimating road traffic up to four decades in the future. Another example can be found in aviation. The Boeing 747 was first 
introduced in the 1960s and aircraft like these can expect to have a service life of up to $30-35$ years [2,3]. It is estimated that $80-100$ years will elapse from the start of initial design of the aircraft to the last one being retired from service [4]. The major aircraft manufacturing companies Boeing and Airbus Industrie both issue annual 20 year forecasts of passenger travel in order to decide what production levels to plan for. Future projections are therefore needed (often at sub-national, national, and global levels), for the volume of travel by each mode, and for the infrastructure to support each mode. Also needed is information on future propulsion systems, and, especially for aircraft, passenger capacity.

Another reason for attempting prediction in transport is energy supply and its consequences. Because of its rapid growth over the past half century, vehicular transport is now the major consumer of oil, and consequently, is also an important producer of greenhouse gas emissions. Future oil availability and future global climate change are important problems in their own right. In their recent report [5], the Intergovernmental Panel on Climate Change (IPCC), projected global temperatures out to 2100 . This projection necessitated emission estimates from the various sectors, including transport. Transport emission estimates in turn required projections of travel by each mode, and the fuels used. Similarly, any discussion on long-term future oil availability needs projections of future oil demand, largely for transport.

For these and other reasons, a large literature on transport forecasting is now available in specialist forecasting journals, as well as in transport journals. Further, a number of predictions for transport technology and travel in the year 2000 and earlier have been made in the past, and it is worthwhile examining some of these. For instance, the International Automobile Program at MIT [6] forecast a world passenger car ownership of 536 million for 2000, using a baseline figure of 310 million for 1979. They arrived at this forecast value by assuming an annual $2.5 \%$ growth in world economic output and a global income elasticity of demand for cars as 1.35. Their projection was well below the 610 million passenger cars estimate in 2000 [7]. In contrast to this rare conservative forecast are many over-optimistic ones. Kahn and Wiener, in their 1967 book 'The Year 2000: A Framework for Speculation on the Next Thirty-Three Years' [8], offered 100 technology forecasts for the year 2000 in a range of subject areas. They were judged to have an $80 \%$ correct prediction rate in the 'communications and computers' area, but only around 30\% for 'infrastructure and transportation' and less than $20 \%$ for 'aerospace'. The authors failed to appreciate that the huge investments needed for undersea colonies, for example, would weigh heavily against their adoption [9]. Other examples of failed predictions for new transport technology in the US include nuclear-powered cars and planes. And in the US today electric vehicles number only a few thousand, not the millions once predicted.

Geels and Smit [10], in their discussion of why forecasts of the impact of the new Information Technology (IT) on transport (in this case teleworker numbers) proved over-optimistic, argue that the main reason was 'because they are based on too simplistic conceptualisations of technological development and its impact on society'. Further, forecasters often neglect 'the dynamic co-evolution of technology and society'. Their arguments can be usefully extended to other forecasts in the transport field. 
The central aim of this paper is to explore what can be known about vehicular travel and technology out to the year 2050. A 50-year horizon allows sufficient time for major changes in both transport technology and lifestyles. The paper examines both air and surface transport, mainly in the Organisation for Economic Cooperation and Development (OECD) countries, and first offers a view on transport technology and travel volume development over the past half century. Future transport is explored by successively examining possible, preferred, and probable transport futures. Finally, ways of dealing with uncertainty in the prediction of transport are suggested. The main conclusion of the paper is that the relative stability in both transport technology and the travel/national income relationship observed over the past half century is unlikely to continue for long, because of several potentially serious constraints on transport.

\section{Transport technology and travel: 1950-2000}

Donald Norman [11] gives the following advice on prediction: examine the same time period in the past that you wish to forecast in the future. Accordingly, transport technology and travel in the period 1950-2000 will be analysed here, although with some global data from 1900-2000. Along with global trends, transport in four countries are examined in detail: Australia, Japan, the UK and the USA. These countries were chosen for their extensive transport statistics, and also to represent each of the four continents from which the OECD draws its members. The 'core OECD' used below, is defined here as the 15-member EU plus Iceland, Norway, Switzerland, Australia and NZ, Canada and the US, and Japan.

No new transport modes have been introduced over the past 50 years; indeed air travel is the only new addition for almost a century. Car, bus, conventional rail, and air travel today dominate vehicular travel, just as they did in 1950. The main surface transport fuels are still petroleum-derived. Vehicle fuels derived from biomass or compressed natural gas together probably powered a higher share of the road fleet in 1950 than is the case today. Even the most popular alternative fuels - LPG and compressed natural gas - are still carbon-based fossil fuels. Car fuel efficiency (vehicle-km/litre) has changed little. Some improvement was made up to 1990, but since then declines have occurred in some countries, for instance the Netherlands, Canada, and the US [12-14]. Although electrification of rail systems has slowly progressed over the last half century, non-electrified services today use diesel rather than the more abundant coal it replaced. Similarly, infrastructure for both surface and air travel has grown enormously in extent, but has changed little in other respects. In the extreme case of Japan, 'national expressways' grew from zero in 1950 (when car ownership was under one per 1000 persons), to over $6000 \mathrm{~km}$ in 2000, with car ownership at around 400 per 1000 persons [15].

Jet propulsion, first introduced into commercial service in 1949, has enabled larger-capacity aircraft and higher speeds. In 1950, for scheduled flights in the US, the average seating capacity was only 38, and average aircraft speed was $290 \mathrm{~km} / \mathrm{hr}$. By the end of the 20th century, average seating capacity had risen to 152 seats and average speed to $657 \mathrm{~km} / \mathrm{hr}$, although both had fallen slightly from their 1983 peak values [13]. Supersonic passenger aircraft were introduced as early as 1969, but with 
only a dozen Concordes ever in service, their share of the aircraft fleet has always been negligible. Nevertheless, today's planes are far more technologically sophisticated than those in use in 1950. Aircraft are still entirely fuelled by petroleum, but unlike cars, they are steadily improving in fuel efficiency. The IPCC [3] estimate that fuel burn per seat-km in today's new jets is $70 \%$ less than that of early jet aircraft, with over half of the improvement coming from engine improvements, the rest from better airframe design.

Forecasts are not only needed for transport technology, but for travel volumes as well, as these determine the size of the transport fleets and infrastructure required. World motorised travel has grown greatly over the past half century. In 1950, cars numbered only about 52 million worldwide, with about $80 \%$ of them in the US alone. By the end of the 20th century car numbers had grown by an order of magnitude, with the great majority still in the countries of the OECD [7,16] (Table 1). Although average global car ownership is now around 100 per 1000 population, very few of the world's population live in countries with national car ownership near that average. In fact, $63 \%$ of the 2000 global population lived in countries with less than 20 cars per 1000 , while $18 \%$ lived in countries - mainly in the core OECD - with greater than 300 cars per 1000 people [7]. The main change since 1950 is that the rest of the core OECD has joined the US in mass car ownership. Car travel has presumably followed a similar pattern.

Air travel was in its infancy in 1950, with the US alone accounting for $60 \%$ of the global total of 27.5 billion passenger-km (bp-k). By the year 2000, air travel had grown one hundredfold (Table 1), although it then fell $4 \%$ in 2001. In contrast to car and air travel, the growth in surface public transport (mainly bus and rail) has been much more modest, so that its share of world travel has fallen continuously over the past 50 years [18]. Overall, world motorised travel grew ten-fold over this period, from about 2.8 trillion to over 30 trillion passenger-km [16,18,19]. Figure 1 shows a plot of total worldwide vehicular travel over the entire 20th century, illustrating its steep rise after 1950 .

Figure 2 shows vehicular travel per capita against Gross National Income (GNI) per capita for the period 1950-2000 for Australia, Japan, the UK, and the US, as well as for the world overall. The GNI data are all converted to constant US 2000 dollars. Purchase parity pricing (PPP) values are used, as these best reflect the actual transport purchasing power of the different currencies [24]. For each country the

Table 1 Distribution of car ownership and air travel, 1950 and $2000[6,7,16,17]$

\begin{tabular}{lcc}
\hline & 1950 & 2000 \\
\hline World cars (million) & 52 & 610 \\
Core OECD & $94 \%$ & $75 \%$ \\
Rest of world & $6 \%$ & $25 \%$ \\
World air travel (bp-k) & 27.5 & 3020 \\
Core OECD & $86 \%$ & $72 \%{ }^{1}$ \\
Rest of world & $14 \%$ & $28 \%{ }^{1}$ \\
\hline
\end{tabular}

${ }^{1}$ Scheduled flights only. 


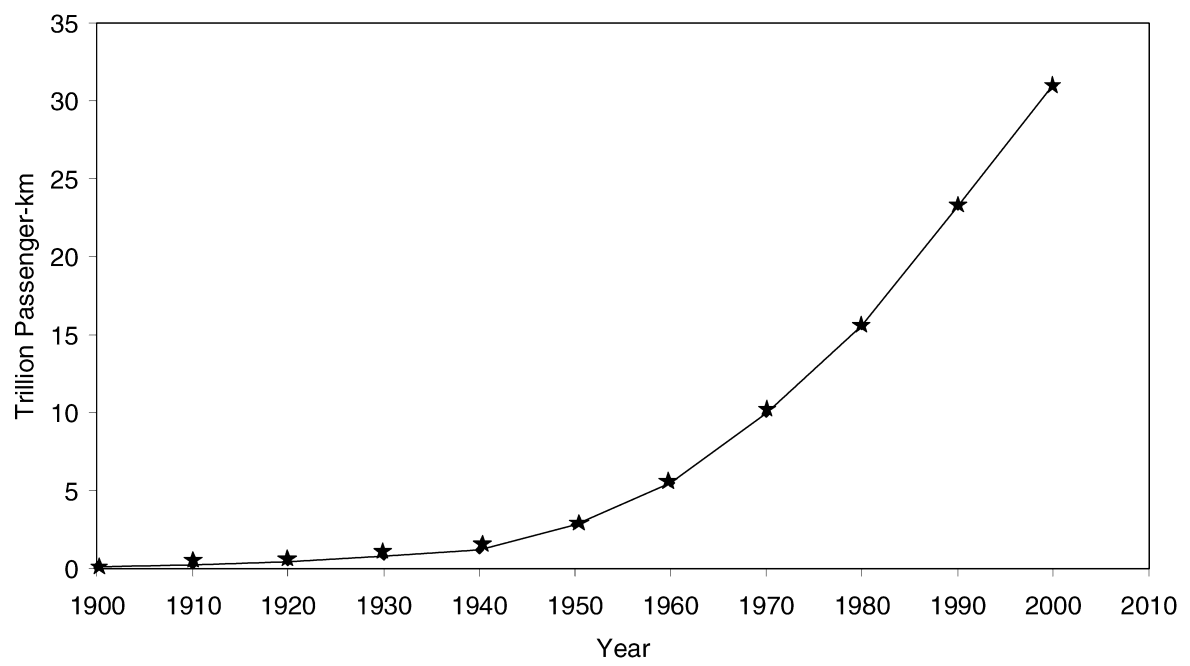

Figure 1 Global vehicular travel, 1900-2000 [7,16-20]

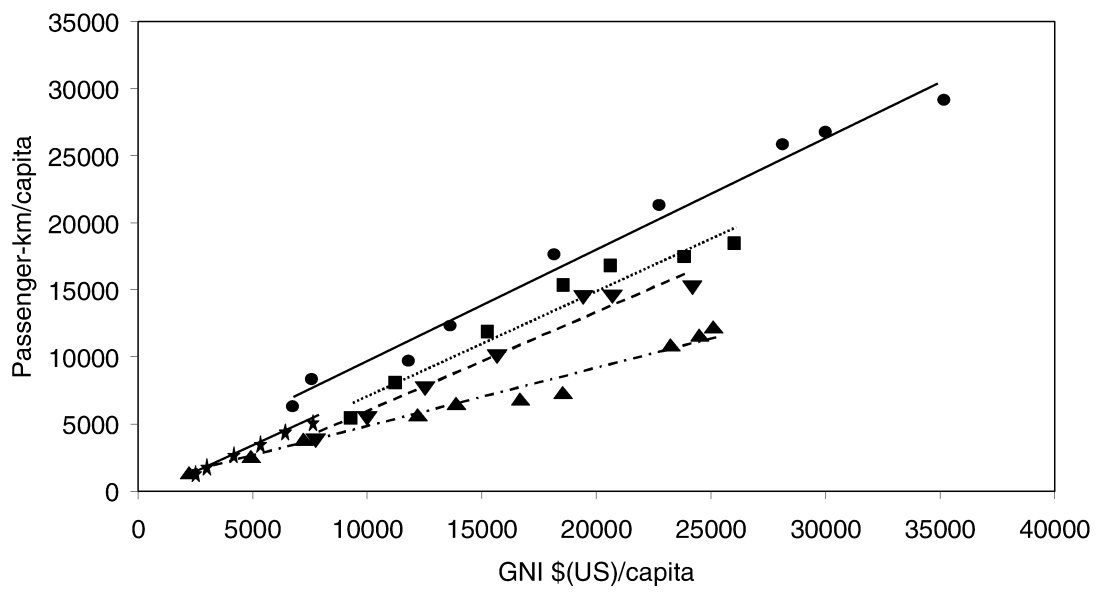

Figure 2 Personal vehicular travel vs GNI/capita (\$US 2000) for 1950-2000 for Australia

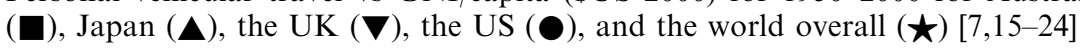

relationship is roughly linear over the entire 50 -year period, although there is some scatter. Globally, the correlation is very good. However, the slope of the lines for individual countries is very different, with that for the US the steepest, and Japan's the flattest. Most of the other core OECD countries, including the UK and Australia, plot between the Japanese and the US curves. The curves show clearly that factors other than GNI per capita are also important in determining travel per capita in any country at a given time.

Figure 2 showed travel for all modes, including air. When surface modes only are considered, and surface travel per capita is plotted against year, the curves for Australia, Japan, and the UK all show a levelling off, beginning around 1990 (Figure 3). Although GNI/capita in Japan grew at only $1 \%$ per annum from 1990-2000, in the UK and Australia the corresponding values were 2.1 and $2.9 \%$ respectively [7], so 


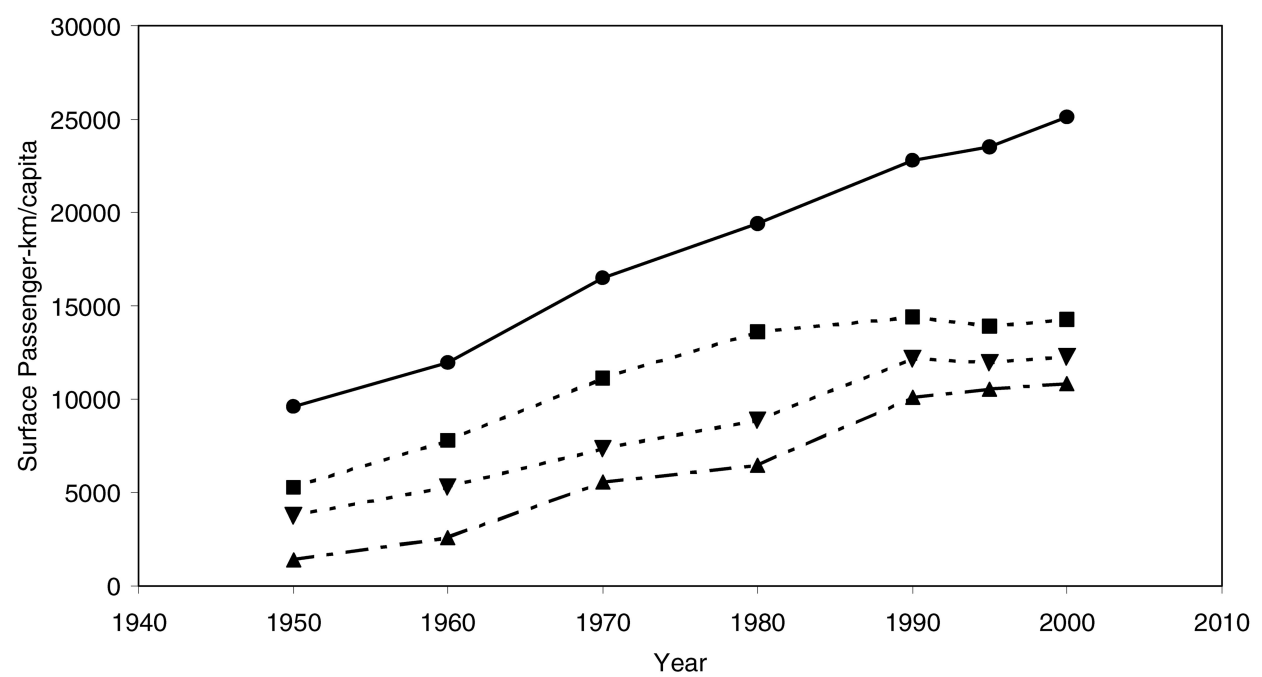

Figure 3 Surface travel per capita vs year for Australia ( $\boldsymbol{\square})$, Japan $(\boldsymbol{\Delta})$, the UK $(\boldsymbol{\nabla})$, and the US $(\bullet)[15,21-23]$

income stagnation cannot explain this levelling off. It seems likely that saturation in levels of personal surface travel is already occurring in a number of core OECD countries.

In summary, over the past 50 years, travel has increased roughly in step with real gross national incomes in the OECD. This growth has been enabled by an accompanying growth in road and air fleets, in road and air travel infrastructure, and in the use of petroleum-derived fuels. Although modal shares have changed, with declines for surface public transport, the main trend for transport technology has been more of the same. For the world as a whole, vehicular transport seems to obey a 'law of the excluded middle', with most people either travelling a lot or very little. It remains to be seen whether these patterns can continue for the next half-century.

\section{Possible transport futures}

The technological progress of the past half-century has made available an enormous range of possibilities for future transport technology; for the next 50 years to 2050, only the physically impossible can be excluded with certainty. Political and economic feasibility are also very important and will of course place constraints on future transport, but they are more difficult to specify. Here it is simply assumed that only transport technologies which are already in use somewhere, exist in prototype, or are at least at the advanced design stage, can make a substantial difference to travel by the year 2050 .

A vast literature is available on technologies for future car travel. The relevant technologies include alternative fuels [14], alternative propulsion systems [25], and intelligent transport [26]. As noted above, petroleum-based fuels still dominate transport. The main alternatives considered for the internal combustion engine include compressed and liquefied natural gas, methanol from natural gas, biomass 
alcohol, and hydrogen. More radical are proposals for electric vehicles, which dispense with the internal combustion engine itself. Early interest in batteries has been largely superseded by a new focus on hydrogen fuel cells as the power source. The Hypercar ${ }^{\circledR}$ [25] and General Motors [27] concept vehicles are examples. Both represent major departures from the century-old basic automobile design, and could even change the way we think about private transport. Materials used for car manufacture could also change, driven by cost, fuel efficiency, and materials recycling considerations $[28,29]$.

Information technology is already important for vehicle navigation and for occupant information, entertainment, and safety. The most revolutionary application of the new information technology, however, is for Automated Highway Systems [26]. On suitably instrumented freeways, specially-equipped groups of cars could travel in close formation without any intervention by the 'drivers'. Advocates claim that automated highways will be safer than ordinary roads. They further argue that driving in close formation will increase highway capacity and reduce air drag and thus fuel consumption.

Train technology has also advanced. Very fast trains, using wheel-on-rail technology, have been in service for decades, first in Japan, then in France, and now in several other countries. In France, peak operational speeds have now reached $350 \mathrm{~km} / \mathrm{hr}$. A novel development dispenses with wheels altogether. Magneticallylevitated trains (maglevs) were pioneered in Japan and Germany, but the first fullscale project is now operating in Shanghai using German technology. This line, costing over one billion \$US, joins central Shanghai with its airport $30 \mathrm{~km}$ away [30]. Unlike wheel-on-rail fast trains, speeds for maglev trains can potentially match those of aircraft. One proposal even envisages continent-wide maglev services in America running in subterranean evacuated tunnels to eliminate air resistance [31].

Air travel could also undergo fundamental changes. New hybrid air vehicles (part-plane, part-airship) are under development in the UK and Germany. These hybrids could carry freight at up to $200 \mathrm{~km} / \mathrm{hr}$ with a range of nearly $10000 \mathrm{~km}$. Smaller versions could be used for sight-seeing passengers [32]. For conventional air travel, the future could see the present large propulsion turbines replaced by many mini-engines located to allow drag reduction, use of intelligent materials, and, in the long-term, fuel cell powered planes with zero emissions [33].

What about the volume of travel itself? Ausubel et al. [31] project transport evolution for the US only, over the next 50-100 years. They argue that the fraction of both time and disposable income people spend on travel is narrowly bounded. Lowcost, high-speed travel is thus the goal of transport systems. They recognise, however, the environmental problems facing continued growth of travel with existing transport fuels. Accordingly, their prescription for 'green mobility' envisages the following changes: hydrogen fuel cell vehicles replacing existing cars, hydrogen fuelled aircraft, and a large role for sub-surface maglevs, from the urban to the continental scale. They point out that a continuation of the 20th century's $2.7 \%$ growth rate in US per capita mobility would mean a manyfold rise over the $21 \mathrm{st}$ century. Personal travel levels would rise to over $100000 \mathrm{p}-\mathrm{k}$ in 2050 , and over 400000 in the year 2100. In marked contrast to these-high travel futures, others see IT ('virtual travel') replacing much vehicular travel, for example some business air travel, by teleconferencing [34]. In summary, technological developments offer 
possibilities for breaking away from oil, or even from existing vehicular technology. They also seem to allow both much higher, as well as much lower, levels of vehicular travel.

\section{Preferred transport futures}

Because all forms of vehicular transport produce externalities, it is not surprising that transport has been the subject of both much government regulation and environmental movement activity. In Europe and Japan, road fuels are subject to heavy taxes. Regulations are in place throughout the OECD to control vehicle pollution emissions, noise levels, speeds, and safety. Governments at various times have mandated standards for fuel efficiency, set up traffic-free precincts in cities, and encouraged both commuter travel ride-sharing and public transport. The state government of California, a leader in emissions control, has gone further and planned to require $10 \%$ of new vehicles sold in that state, beginning in the 2003 model year, to be zero emission vehicles, but has recently dropped this requirement [35]. The state is also attempting to regulate vehicular greenhouse gas emissions. However, on-going court injunctions could delay or prevent implementation of this regulation [36].

It is clear from this brief list that governments already have a great many levers at their disposal to direct the future course of transport in their countries. Further, despite the privatisation of many public transport systems, the degree of government intervention in transport appears to be growing rather than shrinking. For example, after its recent successful debut in London, road pricing is being considered in a number of other OECD countries [37]. Singapore has had a successful system for many years. Road pricing can be used by governments to control traffic levels in areas and at times of greatest congestion, as it is presently been done in London via a congestion tax. In principle, governments do not have to try to predict the future; they can simply plan it. In our day-to-day lives we do not usually forecast; we survey the possibilities and select our preferred option, assuming that the relevant factors are under our control. Similarly, government planners could collect and analyse past transport data, project these trends into the future, and then calculate what numbers (for emissions, or traffic volumes, for example), result from this baseline scenario. If the projected numbers are regarded as being too high, policies - obviously different from the existing ones - can then put in place to achieve the preferred future targets.

A good example of such an approach comes from the Netherlands [12]. A 'business-as-usual' scenario projects car vehicle-km growing by $75 \%$ from 1990 to 2030 , and even more for road freight vehicles and air travel. Overall transport $\mathrm{CO}_{2}$ emissions would rise $59 \%$, despite a $25 \%$ increase in vehicle energy efficiency. However, for the 'environmentally sustainable transport' scenario, $\mathrm{CO}_{2}$ emissions need to be reduced down to only one fifth of their 1990 value, or by $87 \%$ of the projected 2030 figure. The authors detail the optimal mixture of technological changes, shifts to more efficient modes, and reductions in the volume of both vehicular passenger and freight transport that would be required to achieve these very low emission targets. Finally they consider the policy instruments that would be needed to effect the necessary technological changes, modal shifts, and travel 
reductions; these include tradeable emission permits, regulations and land-use policies. They stress that such a radical change could be realised by 2030 only 'if (the perception of) an energy/environmental crisis or disaster occurs in the near future' [12].

Significant public attitude changes can occur, as can be seen in the case of energy efficiency. Its importance is now widely recognised, in the transport sector as well as in the economy as a whole, by policy-makers. In the OECD, energy intensity (total primary energy use/Gross National Income) has fallen for most countries since the 1970s [7,16,24]. In the case of Denmark, it has halved since 1970. Energy intensity is clearly important for sustainability. However, so is transport intensity, which can be defined by analogy with energy intensity as total vehicular pass-km/Gross National Income. As can be inferred from Figure 2, this ratio varies greatly from country to country, being low for Japan and high for the US. Land use factors, particularly the density of urban settlements, are an obvious way of explaining these travel intensity differences. High density countries like Japan are likely to implement policies which favour public transport, such as the provision of low road space per vehicle, or high fuel taxes.

An obvious question that arises with preferred transport futures is: 'Preferred by whom?' Different groups interested in transport want different things. Where agreement can be obtained from all interested parties (e.g. for unleaded petrol) and the necessary legislation enacted, the future is rendered more certain. And where there is not (e.g. California and zero emission vehicles), it can even add to the uncertainty. This potential for values conflict is even greater if we expand the interested parties to include, first, the majority of the world's people who live outside the core OECD, and, second, future generations.

\section{Probable transport futures}

Forecasting the probable future is what most people usually mean by prediction. And we have to try to forecast in transport. Donald Norman [11] has said it well. 'Attempting to predict the future is both foolhardy and essential'. The probable transport future clearly must be drawn from the range of possible futures. But attempts to forecast it also must take account of preferred futures, particularly if these have the force of legislation, as do for example exhaust emission standards.

Schafer and Victor [18,19] have attempted to forecast travel levels for the world as a whole and for 11 world sub-regions for the years 2020 and 2050. They argue that in the industrialised countries of the OECD, both daily travel time budgets and household travel costs (as a share of household disposable income) are fixed. They project that personal travel levels in North America, for example, will rise from the 1990 value of about 23000 , to 58000 passenger- $\mathrm{km}$ per capita by the year 2050. This projection is based on real per capita income increasing at an average annual rate of $1.7 \%$ over the period. Globally, they project total vehicular travel to grow from 23 trillion pass-km (tp-k) in 1990 to 105 tp-k in the year 2050.

Because of their assumption of fixed travel time budgets, the authors see highspeed modes growing at the expense of slower modes as personal travel levels rise. For the US, they forecast absolute declines in per capita car travel. Worldwide, they project high-speed travel (air and high-speed rail) increasing from the 1990 figure of 
2.2 tp-k to 12.8 tp-k in 2020 and 37.4 tp-k in 2050. (In 1990, air travel accounted for over $95 \%$ of all high speed travel.) The figures for 2020 can be contrasted with the single point projections by Boeing and Airbus for world air travel in 2020 [38]. They both forecast around $8.5 \mathrm{tp}-\mathrm{k}$ for that year, assuming that air travel grows at nearly $5 \%$ per annum.

Earlier, it was shown that for the four OECD countries considered, and particularly for the world as a whole, travel/capita versus GNI/capita has maintained a roughly linear relationship for at least 50 years (Figure 2). The advantage of a trend continuing for many decades is that there is far more chance of unusual events (or 'discontinuities' [39]), happening than for a short-term trend. The spike in real oil prices in the 1970s is an example. If the travel vs GNI relationship survives largely unchanged by these crises, as well as by the various post-war recessions, then our confidence that the trend will continue is strengthened. If the travel vs GNI relationship is seen as a 'megatrend', then linear extrapolation offers yet another travel forecast for the years ahead. Using 1980 as the base year, this simple link between income and travel proved remarkably successful in forecasting global travel for the year 2000, as well as the world car fleet [20]. Projecting the line for world travel (Figure 2) out to 2050, assuming a 3\% global GNI growth, and a population of 8.92 billion [40], gives around 140 trillion p-k (at 16,000 per capita), much larger than Schafer and Victor's estimate. Similarly, extrapolating the US line to 2050, again assuming 3\% annual real GNI growth, would give about 90,000 p-k per capita.

However, not all present travel trends when extrapolated into the future will necessarily be upward. Figure 3 showed that surface travel/capita is now roughly constant in at least some OECD countries. These recent trends, if they were to continue, would indicate absolute declines in future surface travel in countries such as Japan, given that the UN anticipates its population (and those in many European countries, both east and west) will soon begin to decline, reversing a centuries'-old trend of continuous population increase (Table 2). The estimates in the table for 2050

Table 2 UN mid-year population estimates for various countries, 1950, 2000, and 2050 [40]

\begin{tabular}{lcccc}
\hline $\begin{array}{l}\text { Country/ } \\
\text { region }\end{array}$ & $\begin{array}{c}\text { Pop. }(\mathrm{m} .) \\
\text { in 1950 } \\
\text { (actual) }\end{array}$ & $\begin{array}{c}\text { Pop. }(\mathrm{m} .) \\
\text { in 2000 } \\
\text { (actual) }\end{array}$ & $\begin{array}{c}\text { Pop. }(\mathrm{m} .) \\
\text { in 2050 } \\
\text { (low estimate) }\end{array}$ & $\begin{array}{c}\text { Pop. }(\mathrm{m} .) \\
\text { in 2050 } \\
\text { (high estimate) }\end{array}$ \\
\hline France & 41.8 & 59.3 & 54.7 & 72.8 \\
Germany & 68.4 & 82.3 & 72.0 & 87.6 \\
Italy & 47.1 & 57.5 & 41.4 & 48.6 \\
Russia & 102.7 & 145.6 & 91.9 & 111.9 \\
Spain & 28.0 & 40.8 & 32.9 & 42.3 \\
UK & 49.8 & 58.7 & 59.1 & 74.0 \\
All Europe & 547.4 & 728.0 & 564.7 & 704.8 \\
Australia & 8.2 & 19.2 & 23.2 & 28.2 \\
Japan & 83.6 & 127.0 & 100.9 & 119.6 \\
USA & 157.8 & 285.0 & 354.9 & 469.6 \\
World & 2519.4 & 6070.6 & 7408.6 & 10633.4 \\
\hline
\end{tabular}


take into account likely levels of immigration as well as natural increase/decrease [40]. If absolute levels of vehicle-km also fall, road congestion problems in Japan and Western Europe could ease in the coming decades.

Travel volumes over the next 50 years can only continue the trend of the previous 50 years if relevant conditions continue unchanged. These trends can be likened to the trajectory of a ball set in motion toward a far-distant energy-absorbing barrier. The ball's uniform motion must end at the barrier, even if the collision is some 50 years distant. Figure 2 shows trends which are linear for vehicular travel vs GNI extending back 50 years. Some researchers believe that there are barriers, or constraints, which must soon halt this long-term linear progression of travel with income.

The most important constraints are those that could be imposed by global oil depletion and associated oil supply insecurity [41], and climatic change from rising levels of heat-trapping greenhouse gases $[5,42]$. However, unlike the constraint in the analogy, experts disagree on the severity and even the reality of these constraints. For global warming, for example, scientists estimate that a doubling of $\mathrm{CO}_{2}$ equivalent in the atmosphere will raise the earth's surface temperature by between 1.5 and 4.5 degrees Celsius, or even higher [43-45]. Experts also dispute whether or not the constraints can be ameliorated by technical fixes should these problems prove serious for transport. Thus some see alternative fuels, including hydrogen, as completely solving transport's oil and greenhouse gas emission problems [25,31], while others are sceptical [46]. These two potential constraints are global, but another important possible constraint is regional. Traffic congestion is a continuing problem for the core OECD countries, but has not prevented them becoming car-oriented societies. However, in the cities of industrialising Asia, urban traffic congestion is already severe [47], even though car ownership is still low by OECD standards. It could pose a constraint to achieving future levels of urban car travel anywhere near those of the West, even if incomes continue to rise. The constraint is again merely a potential one because it could conceivably be overcome at very great cost by an ambitious urban road-building program, or by the use of much smaller vehicles [26].

These three possible constraints make future transport technology and travel levels very difficult to predict, compared with the last half century. It is not the existence of the constraints that pose a problem for forecasting; it is the uncertainty of their effects for transport. Once known, the barrier in the above analogy will drastically alter a long-term trend, but its effects can be predetermined, hence predicted. When we add in the possible effects of deliberate acts of sabotage, the new Information Technology, including electronic road pricing, and an ageing and possibly declining population in many OECD countries, the difficulties for prediction are magnified. Nevertheless continued failure to respond to a possible transport constraint may render a timely response very difficult.

Indeed, Smil [48], after surveying the dismal record of long range energy forecasting, concluded that single point forecasts were not very useful. They are only useful when the predictive models are very powerful, as is the case for predicting future planetary positions. Single point forecasts are still useful for short-term transport forecasting, of course, based on extrapolating trends. The forecasts could still be in error, but the implicit assumption made that the constraints just discussed will not act in the very short term is a reasonable one. 


\section{Responses to future transport uncertainty}

Of course, if there is too much uncertainty about the future, any attempts at prediction are pointless. All we are left with is the envelope of possible futures, from which the actual future must emerge. Such is the case with card games; all we can know beforehand is that our hand must be some grouping of the 52 cards in the pack. In general, we attempt to forecast because we believe that at least some part of the future is predictable. If so, separating out the predictable from the inherently uncertain is useful $[39,49]$. In transport, the future form of infrastructure is much easier to predict than transport technology and travel volumes, because of its long service life, which is usually greater than the 50 year forecasting horizon used here. We need to continuously monitor for extreme, unpredictable, events, as well as having policies in place to dampen their undesirable effects. In general, we need to adopt strategies which are less dependent on forecasts if the future is uncertain [50].

One way of dealing with ever-widening uncertainty as we try to look progressively further ahead is to use scenario analysis. Smil [48] advocated the use of scenarios to explore the implications of possible futures. For organisations, they can also be used to broaden the horizons of decision makers, to help them break away from 'business as usual' mental models [49]. One advantage of scenarios is that they can potentially avoid the 'big mistake' [50] common in much forecasting, which is to assume that existing social practices will remain unchanged in the future, despite technological advance and economic growth. In transport, many scenarios have already been developed, covering a wide range of possible transport futures. Various researchers have explored low oil-use futures, low travel futures, and the impacts of new transport-relevant technologies. But, as has been pointed out [51], still we need to have some idea of the probabilities of the various scenarios, if they are to be useful.

The most important response to future uncertainty is to increase the robustness and sustainability of transport systems, given the importance of transport in modern economies. More choice needs to be available in fuel and mode selection, as it is in these areas that unexpected events which could endanger existing transport could occur most rapidly. Alternative propulsion systems may also be needed for alternative fuels. The existing car-based system does have some slack in that present car occupancy rates are typically only about $25-30 \%$. Surface public transport often has low seat occupancy rates also, in contrast to air travel. In addition, a more robust transport system may require less vehicular travel [52]. Reduced travel helps prevent fuel efficiency gains being negated by growth in vehicle-km.

There are some signs that consensus is building for more robust and sustainable transport systems in the OECD, with the European Union leading the way. Governments are giving some encouragement to alternative fuels and power systems, and to more efficient vehicles, although so far with little effect. With time, these efforts can only intensify, as depletion continues in OECD oil fields. The real risk is that these laudable efforts will be too little and too late. All might agree on the need for a sustainable transport system, but disagree on policies to achieve it. What are needed are policies which simultaneously tackle a number of transport's problems, including safety as well as environmental issues. Such policies can build more support because they can draw on different interest groups for support. 


\section{Conclusions}

What will transport technology and travel be like in 2050? Can vehicular travel continue its growth of the past half century? Many argue that it can, because world car ownership is only about 100 per 1000 persons, compared with levels of 400-500 per 1000 persons common in the OECD countries. Similarly, only a small minority of the world's population travel by air in any given year, and a large proportion have never been on an airplane. Catching up with the OECD would entail a vast growth in vehicle fleets and travel.

Examination of global and OECD transport over the 1950-2000 period showed little fundamental change in transport technology, or fuels, or in the trends for their use. True, the new IT is now used extensively in surface vehicles and aircraft, but mainly to support traditional transport modes and practices. No new modes were introduced, although the world's first commercial maglev service was introduced early in the 21st century. For transport infrastructure, vehicle fleets, and travel itself, the past half century has mainly seen more of the same, with rising incomes making the growth possible.

This attachment to long-established modes may seem surprising, given the large range of possibilities opened up by technological development. Only the lack of perceived challenges to existing transport made this stability possible. However, because transport operation produces a number of negative externalities, it has long been subject to government regulation and environmental movement activity, particularly in Europe. In the EU, studies have been made which focus on desirable futures for transport, and how to attain them. Sustainable transport is their aim.

But the next 50 years of transport could produce a break with the well-established trends of the past. Several potential serious constraints, such as oil depletion and global climate change, may well mean that the past will be a poor guide to the future. Projecting 50 years ahead will always be an uncertain exercise, but for transport, this uncertainty looks like increasing. Responding to an uncertain future will prove difficult if change is left largely to market forces. Instead, a larger role for public policies, (including the introduction of policies like carbon taxes) can both reduce uncertainty and provide us with a more robust transport system. For that to happen, more consensus both locally and globally about preferred options will be needed than exist today.

\section{References}

1 Transurban (1996) The Melbourne City Link Prospectus, Transurban, Melbourne.

2 Conger, T. (1996) 'Air transport', in: Encyclopedia of the Future, G. Kurian and G. Molitor (Eds), M.E. Sharpe Inc., Armonk, New York.

3 Intergovernmental Panel on Climate Change (IPCC) (2001) Aviation and the Global Atmosphere. Accessed at www.grida.no/climate/ipcc/aviation/index.htm

4 McClure, J.C. (1999) 'The end of engineering', Forum for Applied Research and Public Policy, Fall, pp. 114-120.

5 Intergovernmental Panel on Climate Change (IPCC) (2001) Summary for Policymakers, A Report of Working Group 1 of the IPCC. Accessed at www.ipcc.ch/pub/spm22-01.pdf 
6 Altschuler, A., Anderson, M., Jones, D., Roos, D. and Womack, J. (1984) The Future of the Automobile, George Allen and Unwin, London.

7 World Bank (2002) World Development Indicators 2002, Oxford U.P., New York (also earlier editions).

8 Kahn, H. and Wiener, A. (1967) The Year 2000: A Framework for Speculation on the Next Thirty-Three Years, Macmillan, New York.

9 Albright, R.E. (2002) 'What can past technology forecasts tell us about the future?', Technological Forecasting \& Social Change, Vol. 69, pp. 443-464.

10 Geels, F.W. and Smit, W.A. (2000) 'Failed technology futures: pitfalls and lessons from an historical survey', Futures, Vol. 32, pp. 867-885.

11 Norman, D. (1993) Things That Make Us Smart, Addison-Wesley Publishing Co., New York.

12 Geurs, K. and van Wee, B. (2000) 'Backcasting to develop a sustainable transport scenario assuming emission reductions of 80-90\%', Innovation, Vol. 13, No. 1, pp. 47-62.

13 US Bureau of the Census (2002) Statistical Abstract of the United States: 2002 (122nd edition) Washington, DC (also earlier editions).

14 McLean, H.L., Lave, L.B. and Griffin, W.M. (2003) 'Alternative transport fuels for the future', Int. J. Vehicle Design, this issue.

15 Statistics Bureau (2002) Statistical Handbook of Japan 2002, Statistics Bureau, Tokyo (also earlier editions).

16 United Nations (2002) Statistical Yearbook, 46th Issue, UN, New York (also earlier editions).

17 Mitchell, B.R. (1992) International Historical Statistics 1750-1988. Three vols, Macmillan, Basingstoke, UK.

18 Schafer, A. (1998) 'The global demand for motorised mobility', Transportation Res.-A, Vol. 32, No. 6, pp. 455-477.

19 Schafer, A. and Victor, D. (2000) 'The future mobility of the world population', Transportation Res.-A, Vol. 34, No. 3, pp. 171-205.

20 Silverleaf, A. and Turgel, J. (1983) 'Reflections on transport in the future', Transport Reviews, Vol. 3, No. 4, pp. 303-327.

21 Australian Bureau of Statistics (ABS) (2003) 2003 Year Book of Australia, No. 85, ABS, Canberra (also earlier editions).

22 Bureau of Transportation Statistics (2003) Pocket Guide to Transportation, BTS03-01, US Department of Transportation, Washington, DC (also earlier editions).

23 Department for Transport (2002) Transport Statistics Great Britain: 2002 Edition, The Stationery Office, London. Accessed at www.transtat.dft.gov.uk/tables/tsgbo2/

24 Heston, A., Summers, R. and Aten, B. (2002) Penn World Tables Version 6.1, Centre for International Comparisons, University of Pennsylvania. Accessed at http://pwt.econ. upenn.edu/

25 Lovins, A.B. and Cramer, D.R. (2003) 'Hypercar ${ }^{\mathbb{R}}$, hydrogen and the automotive transition', Int. J. Vehicle Design, this issue.

26 Adams, R. and Brewer, T. (2003) 'A plan for 21 st century land transport', Int. J. Vehicle Design, this issue.

27 Burns, L.D., McCormick, J.B. and Borroni-Bird, C.E. (2002) 'Vehicle of change', Scientific American, October, pp. 40-49.

28 Sutherland, J., Gunther, K., Allen, D., Bauer, D., Bras, B., Gutowski, T., Murphy, C., Piwonka, T., Sheng, P., Thurston, D. and Wolff, E. (2003) 'A global perspective on the environmental challenges facing the automotive industry: state-of-the-art and directions for the future' Int. J. Vehicle Design, this issue. 
29 Veloso, F. and Fuchs, E. (2003) 'The future of the Asian auto industry: regional integration, alternative designs and Chinese leadership', Int. J. Vehicle Design, this issue.

30 Anon (2002) 'Big lift: test run for world's first maglev', ENR, Vol. 249, Issue 27, p. 7.

31 Ausubel, J., Marchetti, C. and Meyer, P. (1998) 'Toward green mobility: the evolution of transport', European Review, Vol. 6, No. 2, pp. 137-156.

32 Scott, P. (2001) 'Big, buoyant and back in business', New Scientist, 6th January, pp. 2023.

33 Goldin, D., Venneri, S.L. and Noor, A. (2001) 'Fresh air, wide-open space', Mechanical Engineering, November, pp. 48-55.

34 Mecham, M. (2002) 'Flying less, irritated more - biz travelers sound off', Aviation Week \& Space Technology, Vol. 156, Issue 17, pp. 64-65.

35 Donlan, T.G. (2003) 'Editorial comment: California dreaming', Barrons, 6th January, p. 35 .

36 Anon (2002) 'United States: Green Davis; California v Detroit', The Economist, Vol. 364, Issue 8283 , p. 45.

37 Anon (2003) 'Britain: Ken leads the charge; road pricing', The Economist, Vol. 366, Issue 8312, p. 52.

38 Boeing Corporation (2003) Current Market Outlook 2003, Boeing Marketing (also earlier editions).

39 Ayres, R.U. (2000) 'On forecasting discontinuities', Technological Forecasting \& Social Change, Vol. 65, pp. 81-97.

40 United Nations (2003) UN World Population Prospects. Accessed at http://esa.un.org/ unpp/

41 Laherrere, J. (2003) 'The future of oil', Int. J. Vehicle Design, this issue.

42 Alley, R.B., Marotzke, J. and Nordhaus, W.D. et al. (2003) 'Abrupt climatic change', Science, Vol. 299, pp. 2005-2010.

43 Pearce, F. (2003) 'Heat will soar as haze fades', New Scientist, 7 June, p. 7.

44 Caldeira, K., Jain, A.K. and Hoffert, M.I. (2003) 'Climate sensitivity uncertainty and the need for energy without $\mathrm{CO}_{2}$ emission', Science, Vol. 299, pp. 2052-2054.

45 Allen, M., Raper, S. and Mitchell, J. (2001) 'Uncertainty in the IPCC's third assessment report', Science, Vol. 293, pp. 431, 433.

46 Hoffert, M.I., Caldeira, K. and Benford, G. et al. (2002) 'Advanced technology paths to global climate stability: energy for a greenhouse planet', Science, Vol. 298, pp. 981-987.

47 Moriarty, P. (2000) 'Car travel: Asia cannot follow Australia's path', Road and Transport Research, Vol. 9, No. 2, pp. 32-40.

48 Smil, V. (2000) 'Perils of long-range energy forecasting: reflections on looking far ahead', Technological Forecasting \& Social Change, Vol. 65, pp. 251-264.

49 Van der Heijden, K. (2000) 'Scenarios and forecasting: two perspectives', Technological Forecasting \& Social Change, Vol. 65, pp. 31-36.

50 Koomey, J.G. (2002) 'From my perspective: avoiding "The big mistake" in forecasting technology adoption', Technological Forecasting \& Social Change, Vol. 69, pp. 511-518.

51 Coates, J.F. (2002) Book Review of Energy Needs, Choices, and Possibilities, Scenarios to 2050. Technological Forecasting \& Social Change, Vol. 69, pp. 527-531.

52 Banister, D., Dreborg, K., Hedberg, L., Hunhammar, S., Steen, P. and Akerman, J. (2000) 'Transport policy scenarios for the EU: 2020 images of the future', Innovation, Vol. 13, No. 1, pp. 27-46. 